\title{
Four Determinative Factors in Fournier's Gangrene Mortality
}

\section{Fournier Gangreni Mortalitesinde Belirleyici Dört Faktör}

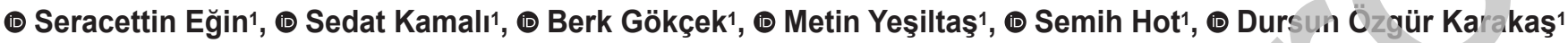 \\ 1 University of Health Sciences, Okmeydanı training and research Hospital, Clinic of General Surgery, İstanbul, Turkey
}

\section{\|IIIIII|| ABSTRACT}

Aim: We aimed to more accurately predict mortality in Fournier's gangrene (FG) by investigating factors affecting mortality such as age, extent of infection, presence of accompanying comorbidities, the intensive care unit (ICU) length of stay (LOS).

Method: Routinely recorded data of 37 FG patients treated between February 2012-May 2018 were retrospectively evaluated. The patients were divided in two groups as the deceased group (DG) $(n=10)$ and surviving group (SG) ( $\mathrm{n}=27)$ and compared in terms of sex, age score (AS), dissemination score (DS), Uludağ Fournier's gangrene severity index (UFGSI) score, Fournier gangrene severity index (FGSI) score, serum urea levels, presence of diabetes and obesity, presence of comorbidities other than diabetes and obesity (COTDO), presence of diversion colostomy, number of days of vacuum-assisted closure treatment, hospital LOS, ICU LOS, and species of isolated bacteria. Associations between mortality and factors such as age, DS, COTDO, and ICU LOS were investigated in all cases.

Results: There was a significant difference between the two groups in terms of AS. DS was significantly higher in the DG than in SG. All of the patients in the DG had COTDO, while only 13 of the patients in the SG had these comorbidities, and the difference between the two groups was statistically significant. ICU LOS was significantly higher in the MG. In reciever operator characteristics curve analysis, UFGSI and FGSI had 93\% specificity and $90 \%$ and $70 \%$ sensitivity, respectively. In logistic regression analysis, age, DS, COTDO, and ICU LOS were independent predictive factors associated with mortality.

Conclusion: Age, DS, COTDO, and ICU LOS showed significant differences between deceased and surviving patients, and emerged as independent predictive factors associated with mortality. As a result, these factors have been shown to be determinative factors in FG mortality.

Keywords: Fournier's gangrene, mortality, vacuum-assisted closure

\section{|IIIIIII|| ÖZ}

Amaç: Fournier gangreninde (FG) mortaliteyi etkileyen yaş, enfeksiyonun yaygınlığı, eşlik eden yandaş hastalıkların varlı̆̆ı, yoğun bakım gün sayısı (YBGS) faktörlerini araştırarak, mortalite öngörüsünü doğru şekilde önceden belirlemektir.

Yöntem: Şubat 2012-Mayıs 2018 arasındaki 37 FG hastasının prospektif kaydedilen verileri retrospektif değerlendirildi. Mortal (grup 1=10 hasta) ve sağ kalan grup (grup 2=27 hasta) olarak iki gruba ayrılan hastalar cinsiyet, yaş skoru (YS), enfeksiyonun yayılım skoru (EYS), Uludağ Fournier gangreni şiddet indeksi (UFGSI) ve Fournier gangreni şiddet indeksi (FGSI) skorları, serum üre düzeyleri, enfeksiyon kaynağı, diyabet, obezite, diyabet ve obezite dışında yandaş hastalık (DODYH) varlığı, saptırıcı stomanın varlığı, vakum yardımlı kapama tedavisi gün sayısı, hastanede kalma gün sayısı, YBGS ve izole edilen bakteri tipleni açıından karşılaştırıldı. Tüm olguların tedavileri sırasında, mortaliteye belirgin etkilerini gözlemlediğimiz yaş, EYS, DODYH varlığ ve YBGS faktörlerinin mortalite üzerindeki etkileri incelendi.

Bulgular: YS bakımından da iki grup arasında anlamlı fark bulundu. EYS grup l'de grup 2'den anlamlı olarak daha yüksekti. Grup l'deki hastaların tamamında ve grup 2'dekilerin 13'ünde DODYH vardı ve iki grup arasında anlamlı fark bulduk. YBGS grup 1 hastalarda anlamlı olarak yüksekti. Alıcı işletim karakteristiğ analizinde, UFGSI'nin $\geq 9$ eşik değer için \%90 duyarlılık ve \%93 özgüllüğe, FGSI'nin $\geq 7$ eşik değer için \%70 duyarlılık ve \%93 özgüllüğe sahip olduğunu saptadık. Lojistik regresyon analizinde, yaş, EYS, DODYH varlığı ve YBGS faktörlerinin mortaliteyle ilgili bağımsız öngörü faktörleri oldugunu bulduk.

Sonuç: Yaş, EYS, DODYH varlığı ve YBGS faktörlerinin gruplar arasında ileri derecede anlamlı farklar göstermesi ve bu faktörlerin mortaliteyle ilgili bağımsız öngorü faktörleri olması, FG'de mortalite öngörülebilirliği konusunda bu faktörlerin belirleyici olduğunu göstermektedir.

Anahtar Kelimeler: Fournier gangreni, mortalite, vakum yardımlı kapama

Address for Correspondence/Yazışma Adresi: Dr. Seracettin Eğin

University of Health Sciences, Okmeydanı training and research Hospital, Clinic of General Surgery, İstanbul, Turkey

Phone: +90 5422134430 E-mail: seracettin_egin@hotmail.com ORCID ID: orcid.org/0000-0002-4090-5205

Received/Geliş Tarihi: 28.07.2018 Accepted/Kabul Tarihi: 27.08.2018

${ }^{\circ}$ Copyright 2018 by Turkish Society of Colon and Rectal Surgery

Turkish Journal of Colorectal Disease published by Galenos Publishing House. 


\section{Introduction}

Fournier's gangrene (FG) is a suppurative bacterial infection of the anorectal, perineal, and genitourinary regions associated with high mortality and morbidity rates. It is a form of synergistic necrotizing fasciitis that causes thrombosis in subcutaneous vessels and results in gangrene in the overlying skin. ${ }^{1,2,3}$ Delays in diagnosis and treatment increase mortality; therefore, symptoms should not be overlooked. The condition requires urgent and aggressive surgical debridement. The disease is named after Jean Alfred Fournier, a Parisian dermatologist and venereologist who presented the first case description in 1883. ${ }^{1,2,4}$ Diabetes is the most common predisposing factor and is present in $20-70 \%$ of cases. ${ }^{2,5}$ Chronic alcoholism is the second most common factor (25-50\%). With all predisposing factors, immune resistance is impaired due to reduced cellular immunity. ${ }^{1}$ Although FG can occur at all ages, its prevalence increases over the age of 50 years. ${ }^{3,4}$ It is considered a disease of poverty. ${ }^{1}$ Urogenital and anorectal infections and trauma are important in its etiology. ${ }^{5}$ In addition to aggressive surgical debridement with effective antibiotic therapy, the basis of treatment is closing the open wound created by debridement with skin flaps or grafts, using vacuum-assisted closure (VAC) systems to accelerating the formation of granulation tissue. Although a consensus has been reached regarding treatment of FG, the factors that determine mortality remain a subject of debate. In articles on this topic, each study group suggests different factors influencing mortality. Despite current advances in treatment, the mortality rate ranges between 3\% and $45 \%{ }^{1}$

The aim of our study was to facilitate the accurate prediction of mortality by investigating factors that affect mortality in FG, including age, extent of infection, comorbidities, and length of stay (LOS) in intensive care. Our hypothesis was that age over 60 years, high dissemination score (DS), presence of comorbidities, and extended LOS in intensive care would increase the expected rate of mortality in patients with FG.

\section{Materials and Methods}

Ethical approval was obtained from the Okmeydanı Training and Research Hospital Ethics Committee. Routinely recorded clata from the medical files of 37 patients treated for FG between February 2012-May 2018 at the General Surgery Clinic of Okmeydanı Training and Research Hospital were retrospectively examined. Data pertaining to the 37 cases were evaluated in terms of age, sex, presence of obesity and comorbidities, etiology of infection, FG severity index (FGSI) score, Uludağ FGSI (UFGSI) score, need for stoma surgery, duration of VAC therapy, hospital LOS, intensive care LOS, mortality, and morbidity to identify factors that affect mortality in FG.

We attempted to establish more accurate prediction of mortality by particularly focusing on four factors we observed in our surgical practice to be closely associated with mortality in the cases examined in this study. Age and extent of infection are factors which have been highlighted in most previous studies and are accepted as directly associated with mortality. In terms of comorbidities, we observed diabetes and obesity in the majority of patients. Besides diabetes and obesity, we also observed greater mortality among patients with diseases such as heart failure, chronic obstructive pulmonary disease, hypertension, and various malignancies. We found it more suitable to evaluate intensive care LOS and presence of comorbidities other than diabetes and besity (COTDO) for comorbidities.

All patients were diagnosed based on physical examination findings. For all patients, oral intake was discontinued at time of presentation to the emergency department and intravenous fluid and antibiotic treatment were initiated. At the same time, our surgical team began operative preparations major surgery. The purpose of surgical debridement is to remove all necrotic tissues, halt dissemination, and reduce systemic toxicity. ${ }^{1}$ Surgical debridement was performed until perfused tissue was reached. Reinspections were done at 24to 48-hour intervals to determine when repeat debridement was necessary, and continued until the infection was well controlled. Fecal diversion was done when necessary to protect the debrided area from contagion. Although there is no general consensus on colostomy, it is recommended in the presence of extensive sphincter damage or large perineal wounds. ${ }^{5}$ The decision to conduct colostomy was made during the second debridement, when the sphincters could be better evaluated and the inflammation had substantially decreased.

Aggressive surgical debridement resulted in large tissue defects in all patients. Wound care is a key component of FG treatment due to the large tissue defects. VAC therapy has gained prominence in recent years and made significant contributions to this extremely difficult phase of the disease by accelerating wound healing with minimal skin defects. ${ }^{6}$ All of our patients underwent VAC therapy after the completion of surgical debridement. VAC dressings were changed at intervals of 3 or 4 days. The final step in the treatment of all patients is closure of the large wound defects following the formation of granulation tissue induced by VAC therapy. In some patients, wound closure was possible with delayed primary suturing or V-Y local advancement flaps. However, split-thickness skin grafts were the most commonly used and preferred method for extensive wounds. 
A total of $37 \mathrm{FG}$ patients ( 21 males and 16 females) over the age of 30 were included in our study. Patients who underwent only VAC therapy after aggressive surgical debridement met the inclusion criteria. Patients who were not treated with VAC after surgical debridement were excluded. These were patients with small, localized regions of involvement which were closed with cutaneous and subcutaneous primary suturing after at least two surgical debridements.

There is no reliable tool to estimate the severity of FG, but scoring systems can be used. An ideal scoring system should provide clear and effective information about the patient and also identify high complication and mortality rates. ${ }^{7}$ Laor et al. ${ }^{8}$ recommended the FGSI, which they created by adapting the acute physiological and chronic health evaluation (APACHE II) score for FG prognosis. They showed that the FGSI score can predict mortality rate with $75 \%$ accuracy and survival rate with $78 \%$ accuracy. The FGSI, which has attracted considerable attention in the literature, is a valid and effective scale commonly used in many studies to determine clinical outcomes of the disease. Yllmazlar et al. ${ }^{9}$ have proposed a new scoring system by adding an age score (AS) and the DS to the FGSI. The most important feature of this scoring system, called the UFGSI, is the dissemination score.

The patients in our study were divided into the deceased (group 1, n=10) and surviving (group 2, $\mathrm{n}=27$ ) groups. Patients in these groups were compared in terms of sex; AS, DS, UFGSI, and FGSI scores; serum urea levels; source of infection; presence of diabetes, obesity, and COTDO; the presence of a diversion stoma; VAC therapy duration, hospital LOS, and intensive care LOS; and species of bacteria isolated from culture. In addition, we evaluated associations between mortality and AS, DS, presence of COTDO, and intensive care LOS, which we observed clinically to have significant impact on mortality in our patients.

\section{Statistical Analys}

Statistical analyses were done in SPSS for Windows version 15.0. The results were evaluated using a Mann-Whitney U test, chi-square test, receiver operating characteristic (ROC) curve analysis, and regression analysis. Differences were considered statistically significant at $\mathrm{p}<0.05$.

\section{Results}

The mortality rate was $27 \%$ (10 patients).There was a significant sex difference between the groups (Table 1). Eight of the deceased patients were female. The mean age of the patients in our study group was $58.10 \pm 14.15$ years. The mean age of the patients in group $1(72.40 \pm 13.49)$ was significantly higher than that of the patients in group 2
$(52.81 \pm 10.32)$ (Table 2). We noted a significant difference between the two groups in terms of AS, which is one of the parameters of the UFGSI $(p=0.003)$ (Table 3$)$. The DS, another of the UFGSI parameters, was also significantly higher in group 1 compared to group 2 (Table 3 ). The UFGSI and FGSI scores of the patients in group 1 were significantly higher than those of group 2 (Figures 1 and 2 ). Heart and respiratory rates, which are UFGSI and FGSI parameters, were significantly higher in group 1 compared to group 2 , while hematocrit values were significantly lower in group 1 than in group $2(\mathrm{p}<0.05)$ (Table 2

When we separately compared the groups scores for each index, there were significant differences between the groups in body temperature, heart rate, respiratory rate, and serum

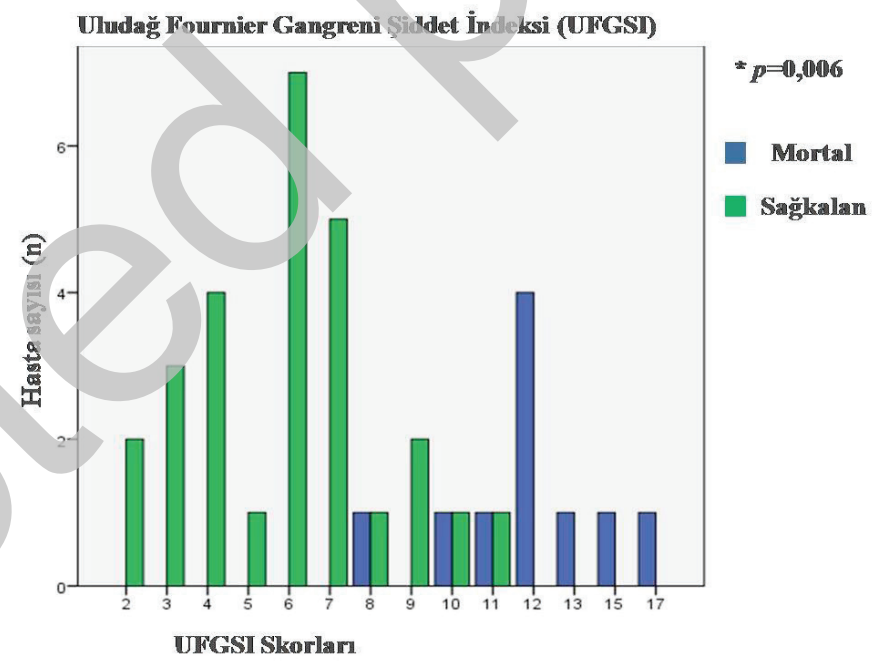

Figure 1. Distribution of patients according to Uludağ Fournier's gangrene severity index

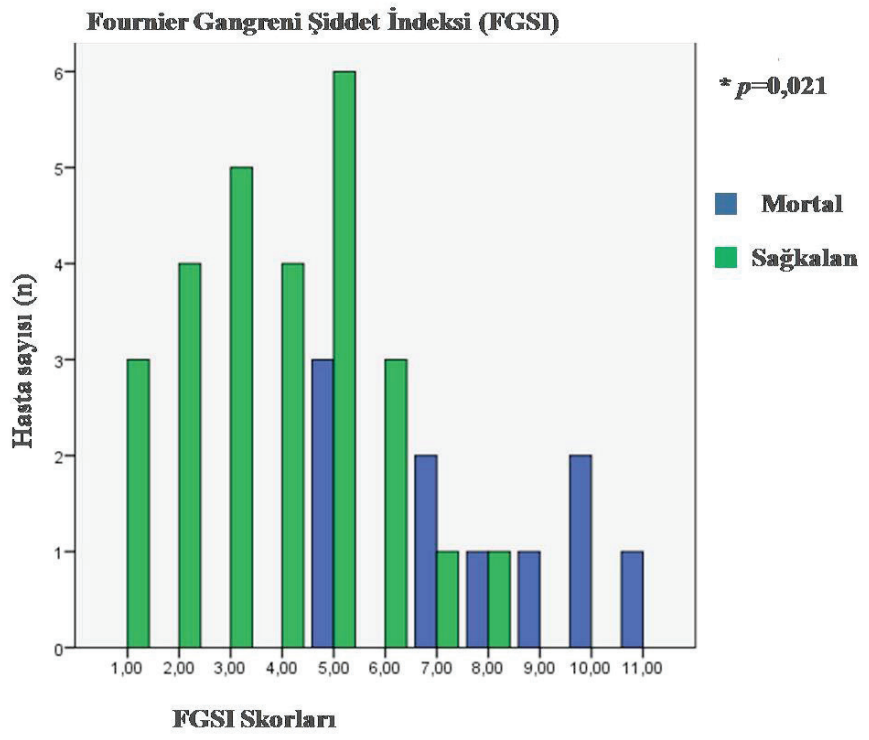

Figure 2. Distribution of patients according to Fournier's gangrene severity index 
potassium and bicarbonate levels $(\mathrm{p}<0.05)$ (Table 3$)$. There was no significant difference between the groups in prevalence of diabetes mellitus (DM) or obesity (Table 1). All of the patients in group 1 and 13 of the patients in group 2 had COTDO $(\mathrm{p}=0.004)$ (Table 1$)$. Intensive care LOS was significantly higher in group 1 patients $(\mathrm{p}=0.0001)$ (Table 2 ). All of the patients in group 1 stayed in the intensive care unit for $21.6 \pm 12.88$ days, while 12 of the patients in group 2 stayed in the intensive care unit for $4.41 \pm 9.07$ days.

Bacterial growth was observed in the wound cultures of 24 patients $(64.8 \%)$. Bacteria were isolated from the cultures of 7 group 1 patients and 17 group 2 patients. The most common bacterium was Escherichia coli, which was isolated in 13 cases (35\%). Other bacteria such as Acinetobacter, Streptococcus, Staphylococcus aureus, Pseudomonas, and Klebsiella were isolated in the wound cultures of 11 patients (29.7\%). No significant difference was found between groups in terms of bacterial growth in cultures (Table 1).

In ROC analysis, the UFGSI had a sensitivity of $90 \%$ and a specificity of $93 \%$ at a threshold value of $\geq 9$. The FGSI had

Table 1. Characteristics of the groups and factors associated with mortality

\begin{tabular}{|c|c|c|c|}
\hline & $\begin{array}{l}\text { Group } 1 \\
\text { (deceased) }\end{array}$ & $\begin{array}{l}\text { Group } 2 \\
\text { (surviving) }\end{array}$ & $\mathrm{p}$ \\
\hline \multicolumn{4}{|l|}{ Sex } \\
\hline Female & 8 & 8 & \\
\hline Male & 2 & 19 & \\
\hline \multicolumn{4}{|c|}{ Infection source } \\
\hline Urogenital & 7 & 15 & 0.42 \\
\hline \multicolumn{4}{|l|}{ Anorectal } \\
\hline \multicolumn{4}{|c|}{ Diabetes mellitus } \\
\hline$(+)$ & 8 & 25 & 0.27 \\
\hline$(-)$ & & 2 & \\
\hline \multicolumn{4}{|c|}{$\begin{array}{l}\text { Comorbid disease } \\
\text { (other than diabetes and obesity) }\end{array}$} \\
\hline$(+)$ & 10 & 13 & $0.004 *$ \\
\hline$(-)$ & 0 & 14 & \\
\hline \multicolumn{4}{|c|}{ Obesity } \\
\hline$(+)$ & 4 & 10 & 0.86 \\
\hline$(-)$ & 6 & 17 & \\
\hline \multicolumn{4}{|l|}{ Bacterial isolate } \\
\hline$(-) \cup$ & 3 & 10 & 0.90 \\
\hline Escherichia coli & 4 & 9 & \\
\hline Other & 3 & 8 & \\
\hline \multicolumn{4}{|c|}{ Diverting colostomy } \\
\hline$(+)$ & 0 & 5 & 0.14 \\
\hline$(-)$ & 10 & 22 & \\
\hline
\end{tabular}

$70 \%$ sensitivity and $93 \%$ specificity with a threshold of $\geq 7$. The ROC curves are presented in Figure 3. The sensitivity, specificity, odds ratios, and positive and negative predictive values for both scoring systems are shown in Table 4.

Table 2. Comparison of parameter means between groups and statistical significance of the differences

\begin{tabular}{|c|c|c|c|}
\hline & $\begin{array}{l}\text { Group } 1 * * \\
\text { (deceased) }\end{array}$ & $\begin{array}{l}\text { Group } 2 * * \\
\text { (surviving }\end{array}$ & $\mathrm{p}$ \\
\hline Age (years) & $72.4 \pm 13.49$ & $52.81 \pm 10.32$ & 0.0001 * \\
\hline $\begin{array}{l}\text { Body temperature } \\
\left({ }^{\circ} \mathrm{C}\right)\end{array}$ & $37.75 \pm 1.01$ & $37.25 \pm$ & 0.139 \\
\hline Heart rate $(/ \mathrm{min})$ & $101=14.8$ & $90.22 \pm 8.79$ & $0.034^{*}$ \\
\hline $\begin{array}{l}\text { Respiratory rate (/ } \\
\text { min) }\end{array}$ & $27 \pm 4.73$ & $23.03 \pm 1.69$ & $0.037^{*}$ \\
\hline $\begin{array}{l}\text { Serum Potassium } \\
(\mathrm{mmol} / \mathrm{L})\end{array}$ & $3.64 \pm$ & $4.16 \pm 0.80$ & 0.072 \\
\hline $\begin{array}{l}\text { Serum Sodium } \\
(\mathrm{mmol} / \mathrm{L})\end{array}$ & $136.4 \pm 4.92$ & $137.18 \pm 4.56$ & 0.801 \\
\hline $\begin{array}{l}\text { Serum Creatinine } \\
(\mathrm{mg} / 100 \mathrm{~mL})\end{array}$ & $1.02 \pm 0.71$ & $1.24 \pm 0.72$ & 0.229 \\
\hline Hematocrit $(\%)$ & $31.12 \pm 4.19$ & $37.28 \pm 6.36$ & $0.009 *$ \\
\hline $\begin{array}{l}\text { Leukocyte count } \\
\left(\mathrm{x} 1000 / \mathrm{mm}^{3}\right)\end{array}$ & $21.13 \pm 4.47$ & $19.38 \pm 5.25$ & 0.353 \\
\hline $\begin{array}{l}\text { Serum bicarbonate, } \\
\text { venous (mmol/L) }\end{array}$ & $22.58 \pm 6.43$ & $22.92 \pm 4.15$ & 0.169 \\
\hline $\begin{array}{l}\text { VAC treatment } \\
\text { duration (days) }\end{array}$ & $32.3 \pm 14.5$ & $28.92 \pm 18.27$ & 0.489 \\
\hline $\begin{array}{l}\text { Hospital length of } \\
\text { stay (days) }\end{array}$ & $38.5 \pm 17.29$ & $41.04 \pm 21.14$ & 0.602 \\
\hline $\begin{array}{l}\text { ICU length of stay } \\
\text { (days) }\end{array}$ & $21.6 \pm 12.88$ & $4.41 \pm 9.07$ & 0.0001 * \\
\hline
\end{tabular}

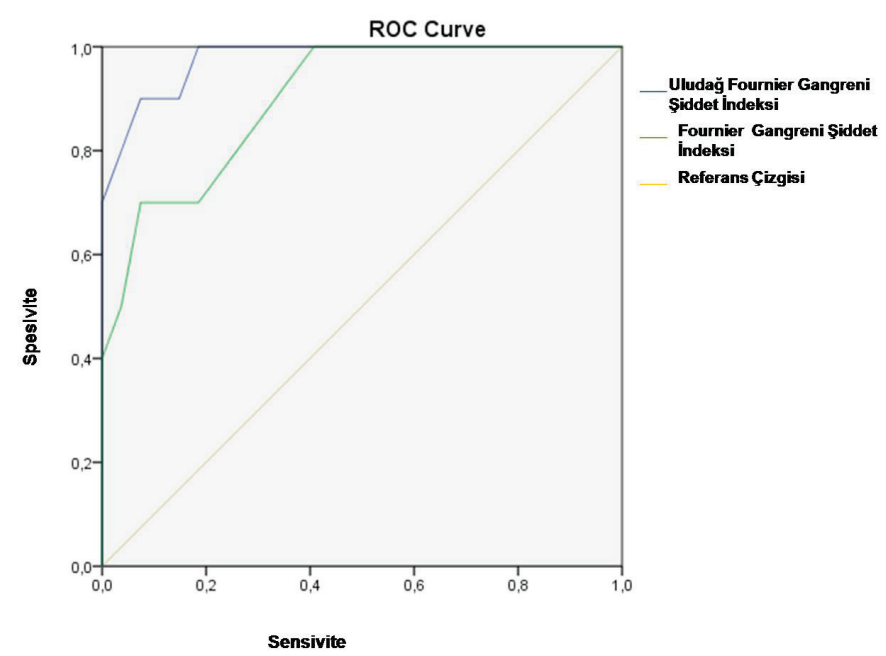

Figure 3. Receiver operating characteristic curves for the Fournier's gangrene severity index and Uludağ Fournier's gangrene severity index 
Table 3. Distribution of Fournier's gangrene severity index and Uludağ Fournier's gangrene severity index scores of the groups

\begin{tabular}{|c|c|c|c|}
\hline & $\begin{array}{l}\text { Group } 1 \\
\text { (deceased) }\end{array}$ & $\begin{array}{l}\text { Group 2 } \\
\text { (surviving) }\end{array}$ & $\mathrm{p}$ \\
\hline \multicolumn{4}{|l|}{ Body temperature score } \\
\hline 0 & 5 & 24 & \multirow[t]{2}{*}{$0.011 *$} \\
\hline 1 & 5 & 3 & \\
\hline \multicolumn{4}{|l|}{ Heart rate score } \\
\hline 0 & 6 & 25 & \multirow[t]{2}{*}{$0.017^{*}$} \\
\hline 2 & 4 & 2 & \\
\hline \multicolumn{4}{|l|}{ Respiratory rate score } \\
\hline 0 & 6 & 26 & \multirow[t]{2}{*}{$0.004 *$} \\
\hline 1 & 4 & 1 & \\
\hline \multicolumn{4}{|l|}{ Serum potassium score } \\
\hline 0 & 2 & 16 & \multirow[t]{3}{*}{$0.016^{*}$} \\
\hline 1 & 6 & 11 & \\
\hline 2 & 2 & 0 & \\
\hline \multicolumn{4}{|l|}{ Serum sodium score } \\
\hline 0 & 9 & 24 & \multirow[t]{2}{*}{0.923} \\
\hline 2 & 1 & 3 & \\
\hline \multicolumn{4}{|l|}{ Serum creatinine score } \\
\hline 0 & 5 & 15 & \multirow[t]{4}{*}{0.81} \\
\hline 2 & 4 & 10 & \\
\hline 3 & 1 & 1 & \\
\hline 4 & 0 & 1 & \\
\hline \multicolumn{4}{|l|}{ Hematocrit score } \\
\hline 0 & 7 & 23 & 0.336 \\
\hline 1 & 0 & 1 & \\
\hline 2 & 3 & 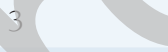 & \\
\hline \multicolumn{4}{|l|}{ Leukocyte score } \\
\hline 0 & 1 & 6 & \multirow[t]{3}{*}{0.617} \\
\hline 1 & 3 & 9 & \\
\hline 2 & 6 & 12 & \\
\hline \multicolumn{4}{|l|}{ Serum bicarbonate score } \\
\hline 0 & 2 & 19 & \multirow[t]{5}{*}{$0.039 *$} \\
\hline 1 & 1 & 1 & \\
\hline 2 & 6 & 6 & \\
\hline 3 & 1 & 0 & \\
\hline 4 & 0 & 1 & \\
\hline \multicolumn{4}{|l|}{ Dissemination score } \\
\hline $\begin{array}{l}\text { Urogenital or anorectal: } \\
1\end{array}$ & 3 & 23 & \multirow[t]{3}{*}{$0.002 *$} \\
\hline $\begin{array}{l}\text { Confined to the pelvic } \\
\text { area: } 2\end{array}$ & 2 & 0 & \\
\hline $\begin{array}{l}\text { Extending beyond the } \\
\text { pelvic area: } 6\end{array}$ & 5 & 4 & \\
\hline \multicolumn{4}{|l|}{ Age score } \\
\hline$<60: 0$ & 2 & 20 & \multirow[t]{2}{*}{$0.003 *$} \\
\hline$\geq 60: 1$ & 8 & 7 & \\
\hline
\end{tabular}

Table 4. Uludağ Fournier's gangrene severity index and Fournier's gangrene severity index results with threshold values

$\begin{array}{lllllll} & \begin{array}{l}\text { Threshold } \\ \text { value } \\ 95 \% \text { CI }\end{array} & \text { Sensitivity Specificity } & \begin{array}{l}\text { Odds } \\ \text { Ratio }\end{array} & \text { PPV } & \text { NPV } \\ \text { UFGSI } & \geq 9 * & 90 \% & 93 \% & 34.86 \% & 71 \% & 85 \% \\ \text { FGSI } & \geq 7 * & 70 \% & 93 \% & 25.13 \% & 66.6 \% & 81.4 \%\end{array}$

CI: Confidence interval, PPV: Positive predictive value, NPV: Negative predictive value, UFGSI: Uludağ Fournier's gangrene severity index, FGSI: Fournier's gangrene severity index

Table 5. Distribution of age, extent of infection score, presence of comorbidities other than diabetes and obesity, and intensive care length of stay in the groups

\begin{tabular}{|c|c|c|c|}
\hline & $\begin{array}{l}\text { Group } 1 \\
\text { (deceased) }\end{array}$ & $\begin{array}{l}\text { Goup } 2 \\
\text { (surviving) }\end{array}$ & $\mathrm{p}$ \\
\hline \multicolumn{4}{|l|}{ Age (years) } \\
\hline & 72.4 & $52.81 \pm 10.32 *$ & $0.0001 *$ \\
\hline \multicolumn{4}{|l|}{ Age score } \\
\hline$<60: 0$ & 2 & 20 & $0.003^{*}$ \\
\hline$>60: 1$ & 8 & 7 & \\
\hline \multicolumn{4}{|c|}{$\begin{array}{l}\text { Comorbidity } \\
\text { (other than diabetes and obesity) }\end{array}$} \\
\hline$(+)>$ & 10 & 13 & $0.004^{*}$ \\
\hline$(-)$ & 0 & 14 & \\
\hline \multicolumn{4}{|l|}{ Dissemination score } \\
\hline $\begin{array}{l}\text { Urogenital or } \\
\text { anorectal: } 1\end{array}$ & 3 & 23 & $0.002 *$ \\
\hline $\begin{array}{l}\text { Confined to the } \\
\text { pelvic area: } 2\end{array}$ & 2 & 0 & \\
\hline $\begin{array}{l}\text { Extending beyond } \\
\text { the pelvic area: } 6\end{array}$ & 5 & 4 & \\
\hline \multicolumn{4}{|c|}{ ICU length of stay (days) } \\
\hline & $21.6 \pm 12.88^{* *}$ & $4.41 \pm 9.07 * *$ & $0.0001 *$ \\
\hline
\end{tabular}

Logistic regression analysis showed that age, DS, presence of COTDO, and intensive care LOS were independent predictive factors associated with mortality (Table 5). In addition, we found that female sex, heart rate, respiratory rate, and hematocrit value were also independent predictive factors associated with mortality.

\section{Discussion}

Prediction of mortality in FG continues to be a controversial topic. While 8 of the 16 females in our study died, only 2 of the 21 males died (Table 1). Comparison of the deceased and surviving groups confirmed that female sex was associated with higher mortality risk and was an independent predictive factor. As in our study, it has also been argued 
in some previous studies that female sex is a risk factor for mortality. ${ }^{10,11}$

Age is an important issue that has consistently emerged as a factor influencing mortality in many studies conducted to date. ${ }^{7,9,12,13}$ We also found significant differences between the groups for patients above and below the age of 60 years (Tables 2 and 3). In addition, our analysis showed that age was an independent predictive factor for mortality.

The second noteworthy finding of our study was that DS was significantly higher in group 1 patients compared to group 2 patients (Tables 3 and 5). In line with the studies reported by Yllmazlar et al.9,14, we found a significant correlation between DS and mortality and determined that it is an independent predictive factor.

Many previous studies have investigated the role of comorbid diseases in mortality. DM, which is considered one of the factors affecting FG, was present in 33 patients $(89 \%)$ in our study (Table 1). However, we were unable to detect a correlation between DM and mortality in this study. Although the prevalence of DM was also high in other studies, DM alone does not impact mortality. ${ }^{7,9,12}$ In our study, we found that although the presence of DM and obesity alone were not associated with mortality, comorbidities such as malignancies, heart failure, and respiratory failure had a significant effect on mortality (Tables 1 and 5). The presence of COTDO was found to be an independent predictive factor for mortality.

In this study, hospital LOS did not differ significantly between the groups, but intensive care LOS was significantly longer in the deceased group (Tables 2 and 5). Intensive care LOS was also observed to be an independent predictive factor for mortality. We did not encounter this result in other publications. This result is also anong the most remarkable findings of our study.

Although the UFGSI and FGSI, which are the most widely used methods for predicting mortality due to FG, have shown acceptably high sensitivity and specificity, both scoring systems are quite complex. Due to this complexity, their implementation is not practical in the clinical setting. We believe that simpler and more practical scoring systems are needed. As mortality is a nearly inevitable outcome in patients with the four salient factors in our study, it may be possible to reduce mortality rates by minimizing intensive care LOS, which is a modifiable risk factor. With early diagnosis and extensive surgical debridement, DS can also be reduced by rapidly localizing infection to restricted areas, thus preventing mortality. The other significant factors in our study, age and comorbidities, are nonmodifiable hostrelated factors.
In our study, scores in the FGSI and UFGSI, which are scoring systems that predict mortality in patients with FG, were associated with mortality. Both scoring systems were found have 93\% specificity (Table 4). Sensitivity was 90\% for the UFGSI and 70\% for the FGSI. Yllmazlar et al. reported $94 \%$ sensitivity and $81 \%$ specificity for the UF GSI. Our results are similar to those reported by Yllmazlar et al. ${ }^{9}$ Roghmann et al. reported $85 \%$ sensitivity and $67 \%$ specificity for the UFGSI. In the aforementioned two studies, sensitivity and specificity for the FGSI were $65 \%-100 \%$ and $88-67 \%$, respectively. In another study by Yilmazlar et al. ${ }^{14}$, no patient with an UFGSI score $\geq 9$ survived in a series of 120 patients. They reported threshold values of 9 and 7 for the UFGSI and FGSI, respectively. In the present study, we also used UFGSI and FGSI score threshoids of 9 and 7, respectively (Table 4). In our study, 9 of the 13 patients with UFGSI scores $\geq 9$ died, while only 1 of the 24 patients with scores of $<9$ died (Figure 1). Seven of the 9 patients with FGSI scores $\geq 7$ died, while 3 of the 28 patients with scores $<7$ died (Figure 2). Although Yllmazlar et a1 ${ }^{9}$ reported no survival for patients with UFGSI scores $\geq 9$ in their series of 120 patients, in our study there were 4 survivors among our patients with UFGSI scores $\geq 9$ (Figure 1). There were also 2 survivors among patients with FGSI scores $\geq 7$. Although these patients had scores above the threshold values and were at high risk of mortality, rapid and extensive debridement and effective treatment resulted in some survivors.

The most common bacterial species encountered in our study was E. coli (Table 1). ${ }^{7,15}$ However, positive cultures and the bacterial species isolated were not associated with mortality.

We never recommend fecal diversion unless the patient has extensive sphincter damage or large perineal wounds. VAC therapy enables less frequent dressing changes, causes less pain, and has similar costs compared to traditional wound dressings in the treatment of FG patients. Using this method, the area of debridement can be kept clean, can heal quickly, and the need for fecal diversion and repeated debridement can be reduced.

Limitations of our study are its retrospective nature and the low number of patients. There are no large patient series pertaining to FG in the literature. The fact that we have a homogeneous patient population managed with the same treatment strategy is a strength of our study.

In conclusion, there are issues that remain to be clarified regarding the prediction of mortality in FG. Simple and practical scoring systems can assist clinicians in terms of modifiable factors that can reduce mortality rates. This study demonstrated very significant differences between deceased and surviving patients in DS, presence of COTDO, and intensive care LOS, and showed that these factors were 
independent predictive factors associated with mortality. Our findings suggest that these factors can serve as predictive indicators of mortality in FG. All of the predictions set forth in our study hypothesis were investigated and all were confirmed. In order for our findings to gain general acceptance in the literature, further research is needed to investigate the mortality predictive factors proposed here in a larger series of FG cases.

\section{Kaynaklar}

1. Eke N. Fournier's gangrene: a review of 1726 cases. Br J Surg. 2000 Jun;87(6):718-28

2. Thwaini A, Khan A, Malik A, Cherian J, Barua J, Shergill I, Mammen K. Fournier's gangrene and its emergency management. Postgrad Med J. 2006 Aug;82(970):516-9

3. Yılmazlar T: Fournier Gangreni. In: Menteş B, Bulut T, Alabaz Ö, Leventoğlu S. Anorektal Bölgenin Selim Hastalıkları. Ankara; BAYT Bilimsel Araştırmalar Basın Yayın ve Tanıtım Ltd. Şti. 2011:267-277.

4. Smith GL, Bunker CB, Dinneen MD. Fournier's gangrene. Br J Urol. 1998 Mar;81(3):347-55.

5. Morpurgo E, Galandiuk S. Fournier's gangrene. Surg Clin North Am. 2002 Dec;82(6):1213-24.

6. Ozturk E, Ozguc H, Yilmazlar T. The use of vacuum assisted closure therapy in the management of Fournier's gangrene. Am J Surg. 2009;197(5):660- 5
7. Roghmann F, Bodman C, Löppenberg B, Hinkel A, Palisaar J, et all. Is there a need for the Fournier's gangrene severity index? Comparison of scoring systems for outcome prediction in patients with Fournier's gangrene. BJU International 2012;110:359-65.

8. Laor E, Palmer LS, Tolia BM, Reid RE, Winter HI. Outcome prediction in patients with Fournier's gangrene. J Urol. 1995 Jul;154(1):89-92.

9. Yilmazlar T, Ozturk E, Ozguc H, Ercan I, Vuruskan H, et all. Fournier's gangrene: an analysis of 80 patients and a novel scoring system. Tech Coloproctol. 2010;14:217-223.

10. Czymek R, Frank P, Limmer S, SchmidtA, Jungbluth T, et all. Fournier's gangrene: is the female gender a risk factor? Langenbecks Arch Surg. 2010 Feb;395(2):173-80.

11. Taviloglu K, Cabioglu N, Cagatay A, Yanar H, Ertekin C, et all. Idiopathic necrotizing fasciitis: risk factors and strategies for management. Am Surg 2005; 71:315-20.

12. Marin AG, Fuentes FT, Ayuso MC, illo JAA Ballesteros JCC, et all. Predictive factors for mortality in fournier's gangrene: A series of 59 cases. Ciresp 2015;93:12-7.

13. Ulug M, Gedik E, Girgin S, Celen MK, Ayaz C. The evaluation of microbiology and Fournier's gangrene severity index in 27 patients. International Joumal of Infectious Diseases 2009;13:424-30.

14. Yılmazlar T, Işılk O, Oztürk E, Özer A, Gülcü B, et all. Fournier's gangrene: Review of 120 patients and predictors of mortality. Ulus Travma Acil Cerrahi Derg 2014:20:333-7.

15. Wróblewsska M, Kuzaka B, Borkowski T, Kuzaka P, Kawecki D, et all. Fournier's gangrene - current concepts. Pol J Microbiol 2014;63:267-73. 


\title{
Fournier Gangreni Mortalitesinde Belirleyici Dört Faktör
}

\section{Four Determinative Factors in Fournier's Gangrene Mortality}

\author{
Seracettin Eğin1, Sedat Kamalı1, Berk Gökçek1, Metin Yeşiltaş¹, Semih Hot'1, Dursun Özgür Karakaş1
}

1Sağlık Bilimleri Üniversitesi, Okmeydanı Eğitim ve Araştırma Hastanesi, Genel Cerrahi Kliniği, İstanbul, Türkiye

\section{|||||||||| ÖZ}

Amaç: Fournier gangreninde (FG) mortaliteyi etkileyen yaş, enfeksiyonun yaygınlığı, eşlik eden yandaş hastalıkların yarlığı, yoğun bakım gün sayısı (YBGS) faktörlerini araştırarak, mortalite öngörüsünü doğru şekilde önceden belirlemektir

Yöntem: Şubat 2012-Mayıs 2018 arasındaki 37 FG hastasının prospektif kaydedilen verileri retrospektif değerlendirildi. Mortal (grup l=10 hasta) ve sağ kalan grup (grup 2=27 hasta) olarak iki gruba ayrılan hastalar cinsiyet, yaş skoru (YS), enfeksiyonun yayılım skoru (EYS), Uludağ Fournier gangreni şiddet indeksi (UFGSI) ve Fournier gangreni şiddet indeksi (FGSI) skorları, serum üre düzeyleri, enfeksiyon kaynağı, diyabet, obezite, diyabet ve obezite dışında yandaş hastalık (DODYH) varlığı, saptırıcı stomanın varlığı, vakum yardımlı kapama tedavisi gün sayısı, hastanede kalma gün sayıSı, YBGS ve izole edilen bakteri tipleri açısından karşılaştırıldı. Tüm olguların tedavileri sırasında, mortaliteye belirgin etkilerini gözlemlediğimiz yaş, EYS, DODYH varlığı ve YBGS faktörlerinin mortalite üzerindeki etkileri incelendi.

Bulgular: YS bakımından da iki grup arasında anlamlı fark bulundu. EYS grup l'de grup 2 den anlamlı olarak daha yüksekti. Grup l'deki hastaların tamamında ve grup 2'dekilerin 13'ünde DODYH vardı ve iki grup arasında anlamlı fark buldluk. YBGS grup 1 hastalarda anlamlı olarak yüksekti. Alıcı işletim karakteristiği analizinde, UFGSI'nin $\geq 9$ eşik değer için \%90 duyarlllık ve \%93 özgüllüğe, FGSI'nin $\geq 7$ eşik değer için \%70 duyarlılık ve \%93 özgüllüğe sahip olduğunu saptadık. Lojistik regresyon analizinde, yas, EYS, DODYH varlığı ve YBGS faktörlerinin mortaliteyle ilgili bağımsız öngörü faktörleri olduğunu bulduk.

Sonuç: Yaş, EYS, DODYH varlığı ve YBGS faktörlerinin gruplar arasında ileri derecede anlamlı farklar göstermesi ve bu faktörlerin mortaliteyle ilgili bağımsız öngörü faktörleri olması, FG'de mortalite öngörülebilirliği konusunda bu faktörlerin belirleyici olduğunu göstermektedir.

Anahtar Kelimeler: Fournier gangreni, mortalite, vakum yardımlı kapama

\section{HIII\|II| ABSTRACT}

Aim: We aimed to more accurately predict mortality in Fournier's gangrene (FG) by investigating factors affecting mortality such as age, extent of infection, presence of accompanying comorbidities, the intensive care unit (ICU) length of stay (LOS).

Method: Routinely recorded data of $37 \mathrm{FG}$ patients treated between February 2012-May 2018 were retrospectively evaluated. The patients were divided in two groups as the deceased group (DG) $(n=10)$ and surviving group (SG) ( $n=27)$ and compared in terms of sex, age score (AS), dissemination score (DS), Uludağ Fournier's gangrene severity index (UFGSI) score, Fournier Gangrene Severity index (FGSI) score, serum urea levels, presence of diabetes and obesity, presence of comorbidities other than diabetes and obesity (COTDO), presence of diversion colostomy, number of days of vacuum-assisted closure treatment, hospital LOS, ICU LOS, and species of isolated bacteria. Associations between mortality and factors such as age, DS, COTDO, and ICU LOS were investigated in all cases.

Results: There was a significant difference between the two groups in terms of AS. DS was significantly higher in the DG than in SG. All of the patients in the DG had COTDO, while only 13 of the patients in the SG had these comorbidities, and the difference between the two groups was statistically significant. ICU LOS was significantly higher in the MG. In receiver operating characteristic curve analysis, UFGSI and FGSI had 93\% specificity and $90 \%$ and $70 \%$ sensitivity, respectively. In logistic regression analysis, age, DS, COTDO, and ICU LOS were independent predictive factors associated with mortality.

Conclusion: Age, DS, COTDO, and ICU LOS showed significant differences between deceased and surviving patients, and emerged as independent predictive factors associated with mortality. As a result, these factors have been shown to be determinative factors in FG mortality.

Keywords: Fournier's gangrene, mortality, vacuum-assisted closure

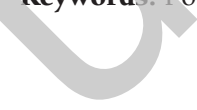

Yazışma Adresi/Address for Correspondence: Dr. Seracettin Eğin

Sağlık Bilimleri Üniversitesi, Okmeydanı Eğitim ve Araştırma Hastanesi, Genel Cerrahi Kliniği, İstanbul, Türkiye

Tel.: +90 5422134430 E-posta: seracettin_egin@hotmail.com ORCID ID: orcid.org/0000-0002-4090-5205

Geliş Tarihi/Received: 28.07.2018 Kabul Tarihi/Accepted: 27.08.2018

${ }^{\ominus}$ Telif Hakkı 2019 Türk Kolon ve Rektum Cerrahi Derneği

Türk Kolon ve Rektum Hastalıklanı Dergisi, Galenos Yayınevi tarafından basılmıştır. 


\section{Giriș}

Fournier gangreni (FG), yüksek mortalite ve morbidite ile seyreden, hızlı ilerleyen, anorektal, perineal ve genitoüriner bölgelerin süpüratif bakteriyel enfeksiyonudur. Subkütanöz damarların trombozisine yol açarak, üzerindeki derinin gangreniyle sonlanan sinerjistik nekrotizan fasiitis halidir. ${ }^{1,2,3}$ Tanı ve tedavi aşamalarındaki gecikmeler mortaliteyi arttırdığından belirtiler gözden kaçırılmamalıdır. Acil ve agresif cerrahi debridmanlar gerektirir. İlk olguyu 1883'te Paris'li bir dermatolog ve venerolog olan Jean Alfred Fournier tanımladığından hastalık onun adıyla anılmaktadır.,2,4 Diyabet \%20-70 oranla en sik görülen predispozan etkendir. ${ }^{2,5}$ Kronik alkolizm \%25-50 oranla ikinci etkendir. Tüm predispozan etkenlerde azalmış hücresel immünite nedeniyle organizmanın bağışıklık direnci bozulmuştur. ${ }^{1}$ FG her yaşta görülmekle beraber 50 yaş üzerinde artış gösterir. ${ }^{3,4}$ Yoksul toplumların hastalığıdır. ${ }^{1}$ Etiyolojide ürogenital ve anorektal enfeksiyonlar ve travma önemlidir. ${ }^{5}$ Agresif cerrahi debridmanlar ile birlikte etkili antibiyotiğin kullanımına ek olarak, cerrahi debridmanlar sonrasında oluşan açı yaraların vakum yardımlı kapama sistemleri ile granülasyon dokusu oluşumunu hızlandırarak deri flepler veya greftleri ile kapatmak tedavinin esasıdır. Günümüzde FG tedavisi konusunda görüş birliği olmasına rağmen, mortaliteyi belirleyici faktörler konusunda tartısmalar halen devam etmektedir. Bu konudaki makalelerde, her çalışma grubu mortalitede etkili olan değişik faktörıeri öne sürmektedir. Günümüzde tedavi yöntemlerindeki gelişmelere rağmen, mortalite $\% 3$ ve $\% 45$ arasında değişen oranlardadır. ${ }^{1}$

Çalışmamızın amacı, FG de mortaliteyi etkileyen yaş, enfeksiyonun yaygınlığı, eşlik eden yandas hastalıkların varlığı, yoğun bakım gün sayısı (YBGS) faktörlerini araştırarak, mortalite öngörüsünü doğru şekilde önceden belirlemektir. Hipotezimiz; yaşın 60 üzerinde olması, enfeksiyonun yayıllım skorunun (EYS) yüksek olması, eşlik eden yandaş hastalıkların varlığı ve YBGS'nın yüksek olması FG olgularında mortalite beklenti oranını yükseltmesidir.

\section{Gereç ve Yöntem}

Etik onay Okmeydanı Eğitim ve Araştırma Hastanesi Etik Kurulu'ndan alındı. Okmeydanı Eğitim ve Araştırma Hastanesi Genel Cerrahi Kliniği'nde Şubat 2012-Mayıs 2018 arasinda FG tanisiyla tedavi uygulanan 37 olgunun prospektif olarak kayit edilen dosya verileri retrospektif olarak incelendi. Otuz yedi olgunun dosya verileri yaş, cins, eşlik eden hastalıklar ve obezite varlığı, enfeksiyonun etiyolojisi, FG Şiddet indeksi (FGSI) skoru, Uludağ FGSI (UFGSI) skoru, stoma gerekliliği, vacuum-assisted closure (VAC) tedavi süresi, yattığı gün sayısı, YBGS, mortalite ve morbidite açısından değerlendirildi. Bu veriler ışığında FG'de mortaliteyi etkileyen faktörler araştırıldı. Arastırma konusu olguların cerrahi pratiğinde, mortalite ile oldukca yakından ilgili olduğu konusunda dikkatimizi çeken dort faktörü özellikle öne çıkararak, mortalite öngörüsünü doğru bir şekilde önceden belirlemeye çalışuk. Yaş ve enfeksiyonun genişliği, daha önceki çalışmaların çoğunda vurgulanan ve mortalite ile direkt ilişkili olduğ konusunda görüş birliği oluşmuş faktorilerdir. Eşlik eden yandaş hastalıklardan diyabet ve obeziteyi hastaların büyük çoğunluğunda gözledik. Diyabet ve obezite dışında, kalp yetmezliği, Kronik Obstruktif Akciğer Hastalı̆̆ hipertansiyon, çeşitli maligniteler gibi hastalıkları olan olgularımızda mortalitenin arttı̆ını gözledik. Yandaş hastalıklar olarak diyabet ve obezite dışında yandaş hastalığ (DODYH) olma ve YBGS incelemeyi daha uygun bulduk. Tüm olguların tanısı fizik muayene bulguları ile konuldu. Tum olgular acil servise geldiklerinde oral alımları kesilerek intravenöz sıvı ve antibiyotik tedavileri başlandı. Cerrahi ekibimiz aynı zamanda büyük bir cerrahi işlem için de operasyonlara hazırlıklı başladı. Cerrahi debridmanların amacı, tüm nekroz olmuş dokuları çıkarmak, enfeksiyonun ilerlemesini durdurmak ve sistemik toksisiteyi azaltmaktır. ${ }^{1}$ Cerrahi debridmanlar, kanlanabilen canlı dokulara kadar gercekleştirildi. Gerekli debridmanlar için 24-48 saat aralar ile yeniden bakılar gerçekleştirildi. Enfeksiyon iyice kontrol edilene kadar yeniden bakılara devam edildi. Gerektiğinde, debridman yapılan alanı bulaştan korumak için fekal saptırmalar yapıldı. Kolostomi için genel bir fikir birliği sağlanamamasına rağmen, yaygın sfinkter hasarı veya geniş perineal yaralar varsa uygulanması önerilir. ${ }^{5}$ Kolostomi açma kararı, sfinkterlerin daha iyi değerlendirilebildiği ve enflamasyonun yüksek oranda azaldığı ikinci debridmanlar sırasında verildi. Agresif cerrahi debridmanlardan sonra, her hastada geniş doku defektleri oluştu. Geniş doku defektleri nedeniyle, FG'de yara bakımı tedavinin önemli bir parçasıdır. Son yıllarda öne çıkan VAC tedavisi, yara iyileşmesini hızlandırarak minimal deri kusurlarıly son derece sorunlu olan bu hastalık dönemine önemli katkılarda bulunmuştur. ${ }^{6}$ Cerrahi debridmanlar tamamlandıktan sonra tüm hastalarımıza VAC tedavisi uygulandı. VAC değişimleri 3 veya 4 günlük aralıklarla yapıldı. Tüm olguların tedavisinde son adım, granülasyon dokusunun oluşumunun VAC tedavisiyle sağlanmasını takiben büyük yara defektlerinin kapatılma işlemleridir. Bazı olgularımızda, bu yaraların kapanması gecikmiş primer sütür veya V-Y lokal ilerleme flepleri ile mümkün olabildi. Ancak, bölünmüss kalınlıkta deri greftleri yaygın yaralar için en çok kullanılan ve tercih edilen yöntem idi. Çalışmamıza, 30 yaş üzerinde 21 erkek ve 16 kadın toplam 37 FG hastası dahil edildi. Agresif cerrahi debridmanlardan 
sonra sadece VAC tedavisi uygulanan hastalar çalışmaya dahil edilme kriterimizdi. Cerrahi debridmanlardan sonra VAC tedavisi uygulanmayan hastalar hariç tutuldu. Bu hastalar küçük lokalize bölgelerin etkilendiği ve en az iki cerrahi debridman sonrasında deri ve deri altı primer sütür ile kapatılmış hastalardı. FG şiddetini tahmin etmek için güvenilir bir araç yoktur, ancak bu görevi yerine getirmek için puanlama sistemleri kullanılabilir. İdeal bir skorlama sistemi hasta hakkında net ve etkili bilgiler sağlamalı ve ayrıca yüksek komplikasyon ve mortalite oranlarını da tanımlamalıdır. ${ }^{7}$ Laor ve ark. ${ }^{8}$ hastalığın prognozuna ilişkin akut fizyolojik ve kronik sağlık değerlendirmesi (APACHE II) skorunu uyarlayarak FGSI önerdiler. FGSI skorunun ölüm oranı için \%75, sağ kalım oranı için \%78 doğruluk ile tahmin edilebileceğini göstermişlerdir. Literatürde kayda değer ilgi uyandıran FGSI skoru, hastalığın klinik sonuçlarını belirlemek için birçok çalışmada yaygın olarak kullanılan geçerli ve etkili bir skordur. Yılmazlar ve ark. ${ }^{9}$ tarafından, FGSI'ya yass skoru (YS) ve EYS eklenerek yeni bir puanlama sistemi önerilmiştir. UFGSI skoru olarak adlandırılan bu skorlama sisteminin en önemli özelliği, enfeksiyonun yayllımının derecelendirilmesidir. Hastalar, mortal (grup $1=10$ hasta) ve sağ kalan grup (grup 2=27 hasta) olarak iki gruba ayrıldı. İki gruptaki hastalar cinsiyet, YS, EYS, UFGSI ve FGSI skorları, serum üre düzeyleri, enfeksiyon kaynağı, diyabet, obezite, DODYH varlığı, saptırıcı stomanın varlığı, VAC tedavisi gün sayısı, hastanede kalma gün sayısı, YBGS ve izole edilen bakteri tipleri açısından karşılaştırıldı. Tüm olgularm tedavileri sırasında, mortaliteye belirgin etkilerini gözlemledigimiz YS, EYS, DODYH varlığı ve YBGS faktölerinin mortalite üzerindeki etkileri incelendi.

\section{İstatistiksel Analizler}

Windows sürüm 15.0 için SPSS kullanılarak yapıldı. Sonuçlar Mann-Whitney U, ki-kare, receiver operating characteristic (ROC) testi ve regresyon analizi ile değerlendirildi. Farklar, $\mathrm{p}<0,05$ düzeyinde istatistiksel olarak anlamlı kabul edildi.

\section{Bulgular}

Mortalite oranımız \%27'dir (10 hasta). Gruplar arasında cinsiyet açısından anlamlı fark bulduk (Tablo 1). Mortal gruptaki 8 hasta kadındı. Çalışma grubumuzdaki hastaların yaş ortalaması $58,10 \pm 14,15$ idi. Grup l'deki hastalarun yaş ortalaması $(72,40 \pm 13,49)$ grup 2'deki hastaların yaş ortalamasından $(52,81 \pm 10,32)$ anlamlı olarak daha yüksekti (Tablo 2). UFGSI parametrelerinden olan YS bakımından da iki grup arasında anlamlı fark bulduk $(\mathrm{p}=0,003)$ (Tablo 3$)$. UFGSI parametrelerinden olan EYS grup l'de grup 2'den anlamlı olarak daha yüksek bulundu (Tablo 3). Grup l'deki hastaların UFGSI ve FGSI skorları, grup 2'deki hastaların skorlarına göre anlamlı olarak daha yüksekti (Resim 1 ve 2). UFGSI ve FGSI parametreleri olan kalp ve solunum hizı grup l'de grup 2'den anlamlı olarak yüksek bulunurken, hematokrit değerleri grup l'de grup 2'den anlamlı olarak daha düşük bulundu $(\mathrm{p}<0,05)$ (Tablo 2). Her iki skorlama sistemine ait skorları gruplar arasında ayrı ayrı karşılaştı dı ğımızda, vücut 1sısı, kalp hızı, solunum hızı, serum potasyum ye bikarbonat skorlarının iki grup arasında anlamlı farklar gösterdiği görüldü $(\mathrm{p}<0,05)$ (Tablo 3$)$. Gruplar arasında diyabetes mellitus (DM) ve obezite açısından anlamlı fark yoktu (Tablo 1). Grup l'deki hastaların tamamında ve grup 2'dekilerin 13'ünde DODYH vardı ve iki grup arasında anlamlı bir fark bulduk $(\mathrm{p}=0,004)$ (Tablo 1). YBGS grup 1 hastalarda anlamlı olarak yüksekti $(\mathrm{p}=0,0001)$ (Tablo 2). Grup 1'deki hastaların tamamı $21,6 \pm 12,88$ gün süre ile yoğun bakım ünitesinde kalırken, grup 2'deki hastaların 12'si 4,41 =9,07 gün süre ile yoğun bakım ünitesinde kaldı. Yirmi dört hastanın $(\% 64,8)$ yara kültürlerinde bakteriyel

Tablo 1. Grupların özellikleri ve mortalite ile ilgili faktörler

\begin{tabular}{|c|c|c|c|}
\hline & $\begin{array}{l}\text { Grup } 1 \\
\text { (mortal) }\end{array}$ & $\begin{array}{l}\text { Grup } 2 \\
\text { (sağ kalan) }\end{array}$ & $\mathrm{p}$ \\
\hline \multicolumn{4}{|l|}{ Cinsiyet } \\
\hline Kadın & 8 & 8 & \multirow{2}{*}{$0,006^{*}$} \\
\hline Erkek & 2 & 19 & \\
\hline \multicolumn{4}{|l|}{ Enfeksiyon kaynağı } \\
\hline Ürogenital & 7 & 15 & \multirow{2}{*}{0,42} \\
\hline Anorektal & 3 & 12 & \\
\hline \multicolumn{4}{|l|}{ Diyabetes mellitus } \\
\hline Var & 8 & 25 & \multirow{2}{*}{0,27} \\
\hline Yok & 2 & 2 & \\
\hline \multicolumn{4}{|c|}{ Yandaş hastalık (diyabet ve obezite dıșında) } \\
\hline Var & 10 & 13 & \multirow{2}{*}{$0,004^{*}$} \\
\hline Yok & 0 & 14 & \\
\hline \multicolumn{4}{|l|}{ Obezite } \\
\hline Var & 4 & 10 & \multirow{2}{*}{0,86} \\
\hline Yok & 6 & 17 & \\
\hline \multicolumn{4}{|c|}{ İzole edilebilen bakteri tipi } \\
\hline Yok & 3 & 10 & \multirow{3}{*}{0,90} \\
\hline Escherichia coli & 4 & 9 & \\
\hline Diğerleri & 3 & 8 & \\
\hline \multicolumn{4}{|l|}{ Saptırıcı kolostomi } \\
\hline Var & 0 & 5 & \multirow{2}{*}{0,14} \\
\hline Yok & 10 & 22 & \\
\hline
\end{tabular}


üreme gözlendi. Grup l'deki hastaların 7'sinde ve grup 2'deki hastaların 17'sinde kültürlerinde bakteri izole edildi. En sık karşılaşılan bakteri, 13 hastada (\%35) mevcut olan Escherichia coli idi. On bir hastanın $(\% 29,7)$ yara kültürlerinde Acinetobacter, Streptococcus, Staphylococcus aureus, Pseudomonas ve Klebsiella gibi diğer bakteriler izole edildi. Kültürlerde bakteri üremesi bakımından gruplar arasında anlamlı fark bulunmadı (Tablo 1). ROC analizinde, UFGSI'nın $\geq 9$ eşik değer için \%90 duyarlılık ve \%93 özgüllüğe sahip olduğunu saptadık. FGSI'ın ise $\geq 7$ eşik değer için \%70 duyarlılık ve \%93 özgüllüğe sahip olduğunu saptadık. ROC eğrileri Resim 3'te sunulmuştur. Ayrıca, her iki skorlama sistemine göre bulunan duyarlılık, özgüllük, olasılık oranı, pozitif öngörü ve negatif öngörü değerleri Tablo 4'te gösterilmiştir. Lojistik regresyon analizi sonucunda, yaş, EYS, DODYH varlığı ve YBGS faktörlerinin mortalite ile ilgili bağımsız öngörü faktörleri olduğunu bulduk (Tablo 5). Ayrica kadın cinsiyetin, kalp hızı sayısının, solunum hızı sayısının ve hematokrit değerinin de mortalite ile ilgili bağımsız öngörü faktörleri olduğunu gördük.

Tablo 2. Gruplar arasındaki parametrelerin ortalamaları ve istatistiksel önemi

\begin{tabular}{|c|c|c|c|}
\hline & $\begin{array}{l}\text { Grup } 1 * * \\
\text { (mortal) }\end{array}$ & $\begin{array}{l}\text { Grup } 2 * * \\
\text { (sağ kalan) }\end{array}$ & $\mathrm{p}$ \\
\hline Yaş (yll) & $72,4 \pm 13,49$ & $52,81 \pm 10,32$ & $0,0001^{*}$ \\
\hline Vücut Isısı $\left({ }^{\circ} \mathrm{C}\right)$ & $37,75 \pm 1,01$ & $\pm 0,60$ & 0,139 \\
\hline Kalp hızı (/dakika) & $101 \pm 14,88$ & $\pm 8,79$ & $0,034^{*}$ \\
\hline Solunum hızı (/dakika) & $27 \pm 4,73$ & $23,03 \pm 1,69$ & $0,037^{*}$ \\
\hline $\begin{array}{l}\text { Serum Potasyum } \\
\text { (milimol/L) }\end{array}$ & $3,64+$ & $\pm 0,80$ & 0,072 \\
\hline $\begin{array}{l}\text { Serum Sodyum } \\
(\mathrm{mmol} / \mathrm{L})\end{array}$ & $136,4 \pm 4,92$ & $137,18 \pm 4,56$ & 0,801 \\
\hline $\begin{array}{l}\text { Serum Kreatinin } \\
(\mathrm{mg} / 100 \mathrm{~mL})\end{array}$ & $1,02 \pm 0,71$ & $1,24 \pm 0,72$ & 0,229 \\
\hline Hematokrit (\%) & $31,12 \pm 4,19$ & $37,28 \pm 6,36$ & $0,009^{*}$ \\
\hline Lökosit (x 1000/mm & $21,13 \pm 4,47$ & $19,38 \pm 5,25$ & 0,353 \\
\hline $\begin{array}{l}\text { Serum bikarbonat, } \\
\text { venöz ( } \mathrm{mmol} / \mathrm{L})\end{array}$ & $22,58 \pm 6,43$ & $22,92 \pm 4,15$ & 0,169 \\
\hline $\begin{array}{l}\text { VAC tedavi süresi } \\
\text { (gün) }\end{array}$ & $32,3 \pm 14,5$ & $28,92 \pm 18,27$ & 0,489 \\
\hline $\begin{array}{l}\text { Hastanede kalış süresi } \\
\text { (gün) }\end{array}$ & $38,5 \pm 17,29$ & $41,04 \pm 21,14$ & 0,602 \\
\hline $\begin{array}{l}\text { Yoğun bakım gün } \\
\text { sayısı }\end{array}$ & $21,6 \pm 12,88$ & $4,41 \pm 9,07$ & $0,0001 *$ \\
\hline \multicolumn{4}{|c|}{ VAC: Vacuum-assisted closure } \\
\hline$* *$ ortalama \pm standart sa & pma & & \\
\hline
\end{tabular}

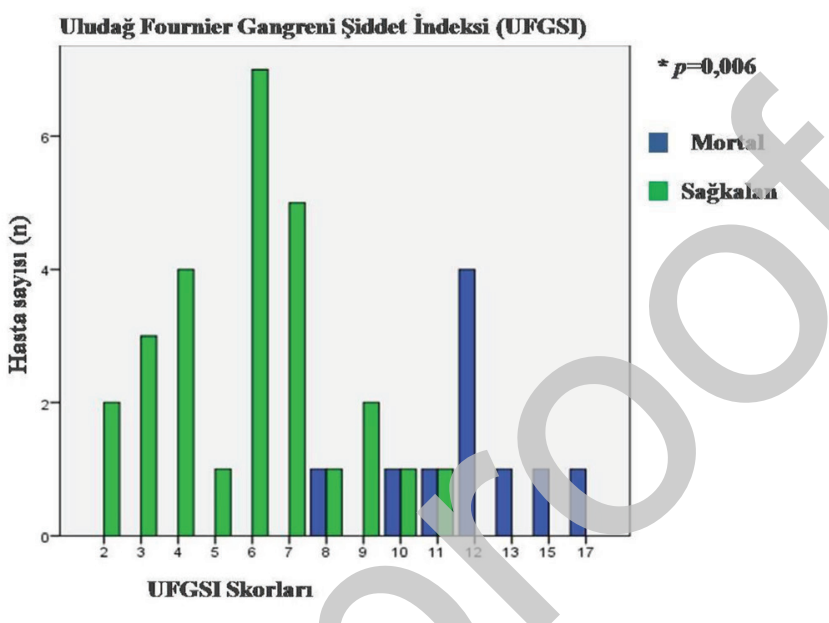

Resim 1. Hastaların Uludağ Fournier gangreni şiddet indeksi skorlama sistemine göre dağılımı

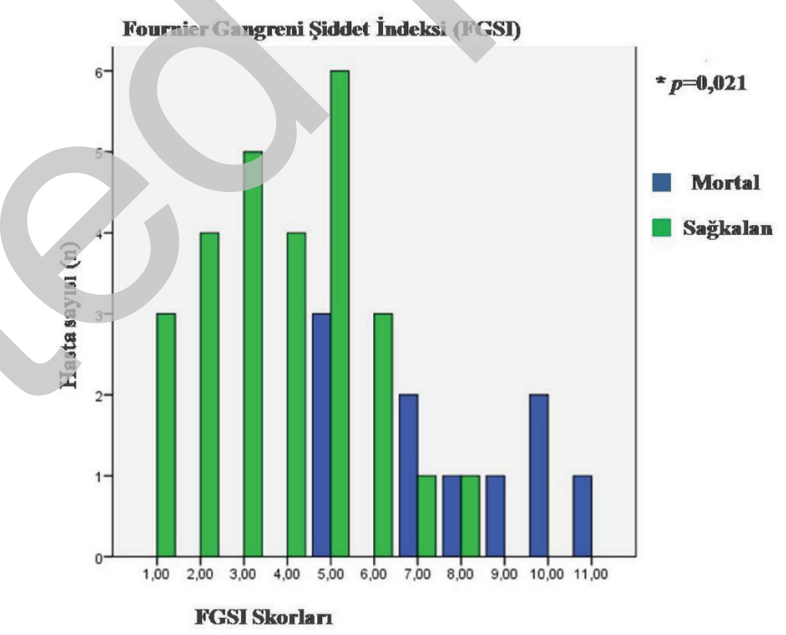

Resim 2. Hastaların Fournier gangreni şiddet indeksi skorlama sistemine göre dağılımı

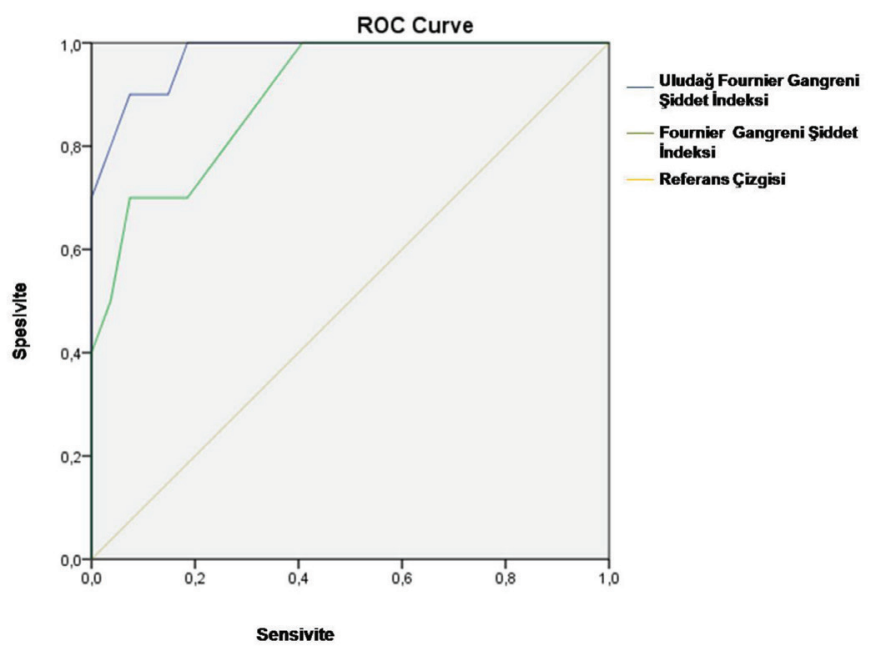

Resim 3. Uludağ Fournier gangreni şiddet indeksi ve Fournier gangreni şiddet indeksi skorlama sistemlerinin receiver operating characteristic eğrisi ROC: Receiver operating characteristic 
Tablo 3. Fournier gangreni şiddet indeksi ve Uludağ Fournier gangreni şiddet indeksi skorlama sistemlerine göre gruplarda skorların dağılımı

$\begin{array}{llll} & \begin{array}{l}\text { Grup 1 } \\ \text { (mortal) }\end{array} & \begin{array}{l}\text { Grup 2 } \\ \text { (sağ kalan) }\end{array} & \mathrm{p} \\ \text { Vücut 1sisı skoru } & & & \\ 0 & 5 & 24 & 0,011^{*} \\ 1 & 5 & 3 & \\ \text { Kalp hizı skoru } & & & 0,017^{*} \\ 0 & 6 & 25 & \\ 2 & 4 & 2 & 0,004^{*} \\ \text { Solunum hizı skoru } & & & \\ 0 & 6 & 26 & 1\end{array}$

Serum potasyum skoru

0
1
2

Serum sodyum skoru

$\begin{array}{lll}0 & 9 & 24 \\ 2 & 1 & 3\end{array}$

Serum kreatinin skoru

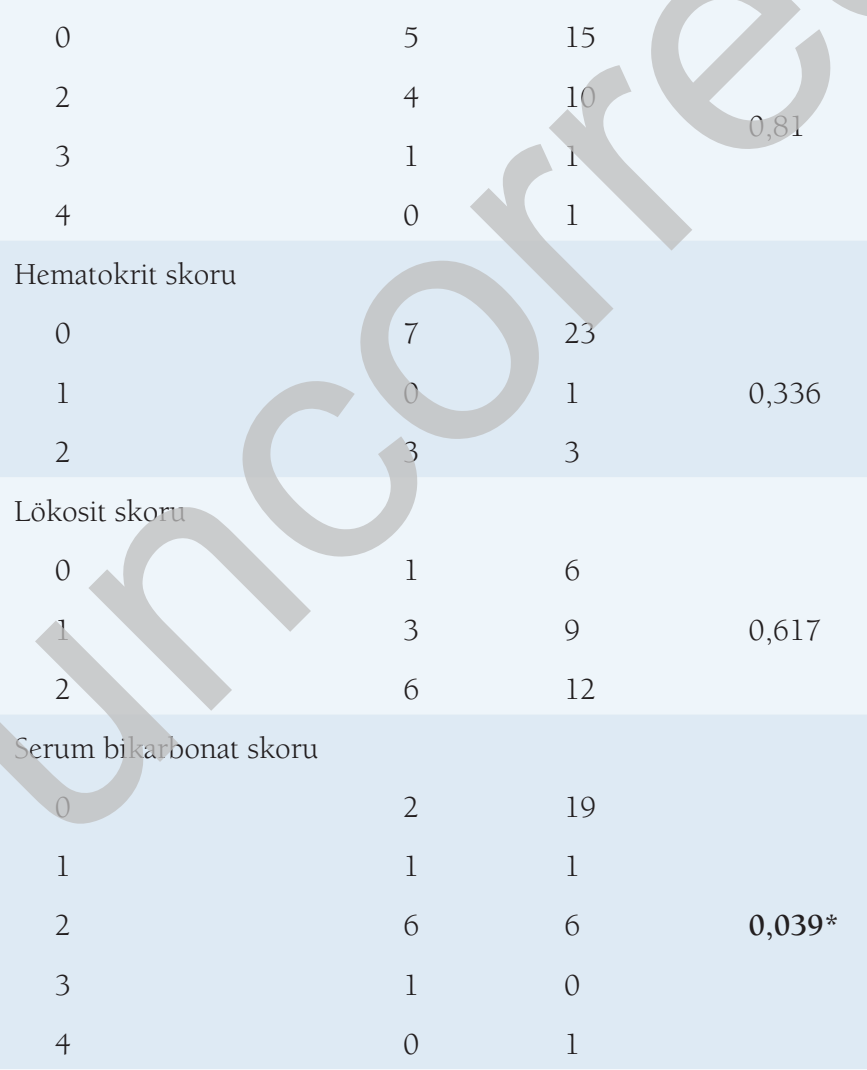

Tablo 3. Devamı

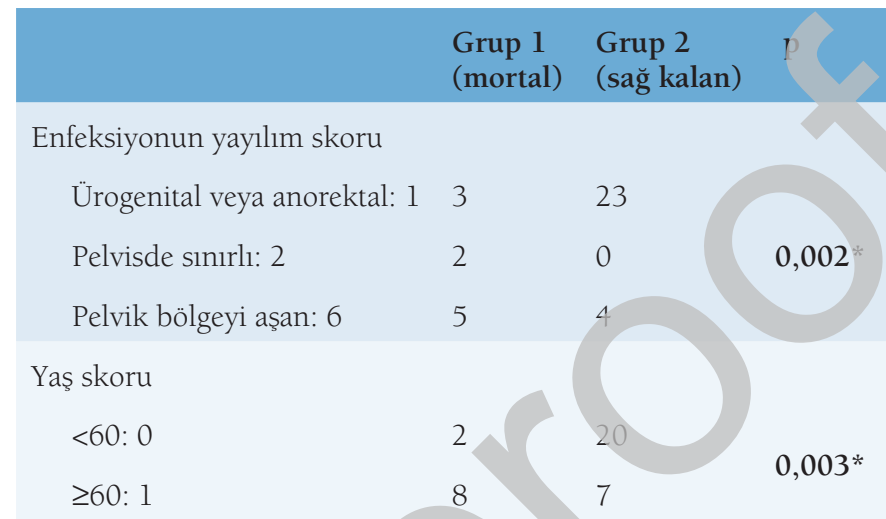

\section{Tartışma}

Günümüzde FG'de mortahitenin öngörülebilirliği konusundaki tartısmalar devam etmektedir. Çalışmamızdaki 16 kadının 8'i mortal sonlanırken, 21 erkeğin ancak 2'si mortal sonlandi (Tablo 1). Gruplar arasında kadın cinsiyetinin mortaliteye daha fazla eğilimli ve bağımsız öngörü faktörü olduğu görüldü. Önceki bazı çalışmalarda da kadın cinsiyetinin mortalite için bir risk faktörü olduğu çalışmamı da olduğu gibi savunulmuştur. ${ }^{10,11}$ Yaş bugüne kadar birçok çalışmada daima mortaliteyi etkileyen bir faktör olarak belirtilen önemli bir konudur., ${ }^{7,9,12,13}$ Biz de çalışmamızda 60 yaş sınırının üstündeki ve altındaki hastalar için gruplar arasında anlamlı sonuçlar bulduk (Tablo 2,3). Ayrıca yaşın mortalite için bağımsız öngörü faktörü olduğu görüldü. Çalışmamızda dikkat çeken ikinci sonuç EYS grup 1 hastalarda grup 2 hastalara göre anlamlı olarak yüksek olmasıdır (Tablo 3 ve 5). Yılmazlar ve ark.9,14 tarafından bildirilen çalışmalarla uyumlu şekilde EYS ile mortalite arasında anlamlı bir ilişki ve bağımsız öngörü faktörü olduğunu bulduk. Günümüze kadar birçok çalışmada, yandaş hastalıkların mortalite üzerindeki rolü araştırılmıştır. Çalışmamızda FG üzerinde etkili faktörlerden biri olarak tartışılan DM, 33 hastada (\%89) mevcuttu (Tablo 1). Bu çalışmada DM ve mortalite arasında bir ilişki bulamadık. Diğer çalışmalarda da DM sıklığı yüksek olmasına rağmen, DM tek başına mortalitede etkili değildir. ${ }^{7,9,12}$ Çalışmamızda, DM ve obezite varlığı tek başına mortaliteyi etkilemese de malignite, kalp yetmezliği ve solunum yetmezliği gibi yandaş hastalıkların mortaliteyi anlamlı derecede etkilediğini saptadık (Tablo 1 ve 5). DODYH varlığının mortalite için bağımsız öngörü faktörü olduğu görüldü. Bu çalışmada hastanede kalış süresi, gruplar arasında anlamlı bulunmazken, YBGS mortal grupta anlamlı olarak daha yüksekti (Tablo 2 ve 5). Mortalite için bağımsız öngörü faktörü olduğu da görüldü. Bu sonuca başka yayınlarda rastlamadık. Bu sonuç aynı zamanda çalışmamızın en dikkat çekici bulgularından biridir. FG'de 
mortalite öngörülebilirliği konusundaki mevcut olan ve en yaygın şekilde kullanılan UFGSI ve FGSI skorları, her ne kadar duyarlılık ve özgüllük konusundaki oranları mevcut çalışmalarda kabul edilebilir oranlarda yüksek çıksa da her iki skorlama sistemi de oldukça karmaşıktır. Karmaşıklıkları nedeniyle de klinik uygulamalarda pratik olmaktan uzaktır. Bu konuda daha basit ve pratik skorlama sistemlerine gerek olduğunu düşünmekteyiz. Çalışmamızda dikkat çeken bu 4 faktöre sahip olan hastalarda mortalitenin kaçınılmaz sonucundan uzaklaşabilmek için, önlenebilir faktörlerden olan YBGS'yi mümkün olduğunca kısa tutabilmek mortalite oranlarını düşürebilir. EYS'de erken tanı ve oldukça geniş cerrahi debridmanlar sayesinde hızlı bir şekilde dar alanlarda lokalize ederek düşük düzeyde tutmak ve mortaliteyi önlemek mümkündür. Çalışmamızda dikkat çeken yaş ve yandaş hastalık varlığı faktörleri hasta ile ilgili olan değiştirilemez faktörlerdir. Çalışmamızda, FG'li hastalarda mortaliteyi öngören FGSI ve UFGSI skorlama sistemlerinin mortalite ile ilişkili olduğu bulundu. Bu çalışmada her iki skorlama sisteminde \%93 özgüllük elde edilmiştir (Tablo 4). Duyarlılık UFGSI için \%90 ve FGSI için \%70 idi. Yılmazlar ve ark. ${ }^{9}$ UFGSI için \%94 duyarlılık ve \%81 özgüllük bildirdi. Çalışmamızdaki bu sonuçlar Yılmazlar ve ark. ${ }^{9}$ tarafından bildirilen çalışma sonuçlarına yakındır. Roghmann ve ark. ${ }^{7}$ UFGSI için $\% 85$ duyarlılik ve \%67 özgüllük bildirdiler. Sözü edilen son iki çalıșmada, FGSI için duyarlılık ve özgüllük sırasıyla $\% 65-\% 100$ ve \%88-\%67 idi. Yllmazlar ve ark. ${ }^{14}$ tarafından yapılan diğer bir çalışmada, 120 hastadan oluşan bir sericle UFGSI skorları $\geq 9$ olan hastalar arasında sağ kalan herhangi bir hasta bildirmediler. UFGSI ve FGS için eşik değerleri sırasıyla 9 ve 7 olarak bildirdiler. Bu çalışmamızda da UFGSI ve FGSI için eşik değerlerinin sırasılyla 9 ve 7 olduğu görüldü (Tablo 4). Çalıs̆mamızda, UFGSI için $\geq 9$ skoru olan 13 olgunun 9'u ölürken <9 olan 24 olgunun sadece 1'i öldü (Resim 1). FGSI için $\geq 7$ skoru olan 9 olgunun 7'si ölürken < 7 olan 28 olgunun 3 üu öldü (Resim 2). Yılmazlar ve ark. ${ }^{9} 120$ hastadan oluşan serisindeki, UFGSI skoru $\geq 9$ olan hastalarda sag kalım bildirilmedikleri halde, biz bu çalışmamızda UFGSI skoru $\geq 9$ olan hastalarımızda 4 sağ kalım bildirmekteyiz (Resim 1). Ayrıca FGSI skoru $\geq 7$ olan hastalanınızda 2 sağ kalım bildirmekteyiz. Eşik değerin

Tablo 4. Eşik değerler için Uludağ Fournier gangreni şiddet indeksi ve Fournier gangreni şiddet indeksi skorlarının sonuçları

$\begin{array}{lllcccc} & \begin{array}{l}\text { Eşik değer } \\ \text { \%95 güven aralığı }\end{array} & \text { Duyarlılık } & \text { Özgüllük } & \text { Olasılık oranı } & (+) \text { Öngörü değeri } & (-) \text { Öngörü değeri } \\ \text { UFGSI } & \geq 9^{*} & \% 90 & \% 93 & \% 34,86 & \% 71 & \% 85 \\ \text { FGSI } & \geq 7^{*} & \% 70 & \% 93 & \% 25,13 & \% 66,6 & \% 81,4\end{array}$

UFGSI: Uludağ Fournier gangreni şiddet indeksi, FGSI: Fournier gangreni şiddet indeksi

Tablo 5. Yaş, enfeksiyon yaygınlık skoru, diyabet ve obezite dışındaki yandaş hastalık varlığı ve yoğun bakım gün sayısı faktörlerinin gruplara dağılımı

\begin{tabular}{|c|c|c|c|}
\hline & $\begin{array}{l}\text { Grup } 1 \\
\text { (Mortal) }\end{array}$ & $\begin{array}{l}\text { Grup } 2 \\
\text { (Sağ kalan) }\end{array}$ & $\mathrm{p}$ \\
\hline Yaş & $72,4 \pm 13,49 * *$ & $52,81 \pm 10,32 * *$ & 0,0001 * \\
\hline \multicolumn{4}{|l|}{ Yaş skoru } \\
\hline$<60: 0$ & 2 & 20 & $0,003 *$ \\
\hline & 8 & 7 & \\
\hline \multicolumn{4}{|c|}{ Yandaş hastalık (Diyabet ve obezite dışında) } \\
\hline & 10 & 13 & $0,004^{*}$ \\
\hline 1 & 0 & 14 & \\
\hline Urogenital veya anorektal: 1 & 3 & 23 & $0,002 *$ \\
\hline Pelvisde sınırlı: 2 & 2 & 0 & \\
\hline Pelvik bölgeyi aşan: 6 & 5 & 4 & \\
\hline Yoğun bakım gün sayısı & $21,6 \pm 12,88 * *$ & $4,41 \pm 9,07 * *$ & $0,0001^{*}$ \\
\hline
\end{tabular}


üstündeki yüksek mortalite riskine sahip bu olgularda, hızlı geniş debridmanlar ve etkili tedaviler uygulandı ve sonuçta bu olgularda sağ kalımlar elde edilebildi. Çalışmamızdaki en sık karşılaştığımız bakteri türü, literatürdeki benzer çalışmalarda belirtildiği gibi Escherichia coli türüdür (Tablo 1). ${ }^{7,15}$ Fakat kültürlerde bakteri üremesinin ve bakteri türünün mortalite üzerine bir etkisi bulunmadı. Yaygın sfinkter hasarı veya geniş perineal yaralar olmadıkça asla fekal saptırma önermeyiz. VAC tedavisi, FG hastalarının tedavisinde geleneksel yara pansumanlarına göre daha az pansuman değişimi, daha az ağrı ve benzer maliyetler sağlar. Böylece debridman bölgesi temiz tutulabilir, hızlı bir şekilde iyileşebilir, ayrıca fekal saptırma ihtiyacı ve debridman sayısı azaltılabilir. Çalışmamızın zayıf yönleri, retrospektif olması ve olgu sayımızın düșük olmasıdır. FG konusunda geniş hasta serileri literatürde yoktur. Aynı tedavi stratejisi ile yönetilen homojen bir hasta popülasyonu olması çalışmamızın güçlü yönüdür. Sonuç olarak, FG'de mortalitenin öngörülebilirliği konusunda halen tartışılması gereken konular vardır. Basit ve pratik skorlama sistemleri, klinisyenlere mortaliteyi azaltan önlenebilir mortalite faktörleri konusunda yardımcı olabilir. Çalışmamızda dikkat çeken yaş, EYS, DODYH varlığı ve YBGS faktörlerinin gruplar arasında ileri derecede anlamlı farklar göstermesi ve bu faktörlerin mortalite ile ilgili bağımsız öngörü faktorieri olması, FG'de mortalite öngörülebilirliği konusunda bu faktörlerin belirleyici olduğunu göstermektedir. Çalışma hipotezimiz ile ilgili öngörülen konular araştırılnıs ve tüm öngörüler doğrulanmıştır. Elde ettiğimiz sonuçların literatürde genel kabul görebilmesi için, ileri surrdüğumüz mortaliteyi belirleyici faktörleri araştıran daha yüksek sayıda FG olgularını içeren serilere ihtiyaç vardır.

\section{Etik}

Etik Kurul Onayı: Çalıșma için Okmeydanı Eğitim ve Araştırma Hastanesi Etik Kurulu'ndan onay alınmıştır (onay numarasi: 05.06.2018/925

Hasta Onayı: Retrospektif çalışma olduğu için hastalardan onay alınmamıştı

\section{Yazarlık Katkılar}

Cerrahi ve Medikal Uygulama: S.E., B.G., M.Y., S.H., D.Ö.K., Konsept: S.E. S.K., Dizayn: S.E., Veri Toplama veya İşleme:
S.E., S.K., Analiz veya Yorumlama: S.E., S.K., Literatür Arama: S.E., Yazan: S.E.

Çıkar Çatışması: Yazarlar tarafından çıkar çatıșması bildirilmemiştir.

Finansal Destek: Yazarlar tarafindan finansal destek almadıkları bildirilmiştir.

\section{Kaynaklar}

1. Eke N. Fournier's gangrene: a review of 1726 cases. Br J Surg. 2000 Jun;87(6):718-28

2. Thwaini A, Khan A, Malik A, Cherian J, Barua J, Shergill I, Mammen K. Fournier's gangrene and its emergency management. Postgrad Med J. 2006 Aug;82(970):516-9

3. Yllmazlar T: Fournier Gangreni. In: Mentes B, Bulut T, Alabaz Ö, Leventoğlu S. Anorektal Bölgenin Selim Hastalıkları. Ankara; BAYT Bilimsel Araştırmalar Basın Yayın ve Tanıtım Ltd. Şti. 2011:267-277.

4. Smith GL, Bunker CB, Dinneen MD. Fournier's gangrene. Br J Urol. 1998 Mar;81(3):347-55.

5. Morpurgo E, Galandiuk S. Fournier's gangrene. Surg Clin North Am. 2002 Dec;82(6):1213-24.

6. Ozturk E, Ozguc H, Yilmazlar T. The use of vacuum assisted closure therapy in the management of Fournier's gangrene. Am J Surg. 2009;197(5):660-5.

7. Roghmann F, Bodman C, Löppenberg B, Hinkel A, Palisaar J, et all. Is there a need for the Fournier's gangrene severity index? Comparison of scoring tems for outcome prediction in patients with Fournier's gangrene. BJU International 2012;110:359-65

Laor E, Palmer LS, Tolia BM, Reid RE, Winter HI. Outcome prediction in patients with Fournier's gangrene. J Urol. 1995 Jul;154(1):89-92.

Yilmazlar T, Ozturk E, Ozguc H, Ercan I, Vuruskan H, et all. Fournier's gangrene: an analysis of 80 patients and a novel scoring system. Tech Coloproctol. 2010;14:217-223

10. Czymek R, Frank P, Limmer S, SchmidtA, Jungbluth T, et all. Fournier's gangrene: is the female gender a risk factor? Langenbecks Arch Surg. 2010 Feb;395(2):173-80.

11. Taviloglu K, Cabioglu N, Cagatay A, Yanar H, Ertekin C, et all. Idiopathic necrotizing fasciitis: risk factors and strategies for management. Am Surg 2005;71:315-20

12. Marin AG, Fuentes FT, Ayuso MC, Lillo JAA, Ballesteros JCC, et all. Predictive factors for mortality in fournier's gangrene: A series of 59 cases. Ciresp 2015;93:12-7.

13. Ulug M, Gedik E, Girgin S, Celen MK, Ayaz C. The evaluation of microbiology and Fournier's gangrene severity index in 27 patients. International Journal of Infectious Diseases 2009;13:424-30.

14. Yılmazlar T, Issılk O, Öztürk E, Özer A, Gülcü B, et all. Fournier's gangrene: Review of 120 patients and predictors of mortality. Ulus Travma Acil Cerrahi Derg 2014;20:333-7.

15. Wróblewska M, Kuzaka B, Borkowski T, Kuzaka P, Kawecki D, et all Fournier's gangrene - current concepts. Pol J Microbiol 2014;63:267-73. 